\title{
Effect of Size of Propagating Material and Planting Distance on Production of Sanders' Dracaena (Dracaena sanderiana Hort.) at Five Shade Intensities ${ }^{1}$
}

\author{
Saulo J. Rodríguez and Carlos Rivera-López ${ }^{2}$
}

\begin{abstract}
A size of propagating material and planting distance experiment was established under 5 shade intensities. The media consisted of Catano sand and shredded peatmoss mixed 3:1 by volume. The experiment was harvested four times during a 36 -month period. The results revealed that, to start a new plantation, the propagating material must be healthy and well developed. The size of harvested cuttings was affected by size of the original planting material. Moreover, the reduction in the planting distance brought a higher gross income per unit area, but mean size and weight of the harvested cuttings were generally reduced at most of the shade percentages tested.
\end{abstract}

\section{INTRODUCTION}

Sanders' Dracaena (D. sanderiana, Hort.) is considered one of the most important foliage ornamental plants in Puerto Rico (1). This member of the lily family is exported either as rooted or unrooted cuttings, or as foil-wrapped or pot-bound plants. Very little research has been reported in the literature on the various horticultural aspects of its culture. The authors recently reported on several aspects of mineral nutrition, including leaf analyses $(2,3,4)$.

Most of the cultural practices have been established through the experience of each operator but not on an experimental basis. In a survey of the different growers, it was found that the plant is being grown under a great diversity of cultural conditions. This finding suggested the establishment of experiments to determine the value of the different cultural aspects. The present paper presents the results obtained in an experiment on the size of propagating material at three planting distances under five shade intensities.

\section{PROCEDURE}

A galvanized iron frame was constructed over a set of $4 \times 4$-ft concrete beds at the Experiment Station Farm at Río Piedras. The frame was covered with five different arrangements of propylene laths so as to provide $47,51,63,76$, and $92 \%$ actual shade. The beds were filled with a $3: 1$ by volume Cataño sand-shredded peatmoss mixture.

\footnotetext{
${ }^{1}$ Manuscript submitted to Editorial Board March 29, 1977.

${ }^{2}$ Horticulturist and former Agronomist, respectively, Agricultural Experiment Station, Mayagüez Campus, University of Puerto Rico, Río Piedras, P.R.
} 
All propagating material was bought as unrooted cuttings from a commercial local nursery. The cuttings were sorted and grouped into three commercial sizes: 4-6, 8-10, and 12-15 in, with mean weights of $6,15.3$, and $27.9 \mathrm{~g}$, respectively.

The sorted cuttings were rooted under a mist propagator. After rooting, they were planted under each of the shade intensities at three different planting distances. The planting distances corresponded to 6 $\times 6,9 \times 9$ and $12 \times 12$ in.

The nine treatments of the factorial experiment were randomly distributed in two replications in each shade intensity. Each replication corresponded to a separate concrete bed.

A 16-4-8 fertilizer mixture was applied four times a year, to provide approximately $500 \mathrm{lb}$ N/acre/yr. The plots were irrigated by sprinklers attached to a plastic tube that ran along the center of each bed. A

TABLE 1. - The effect of size of planting material on the production of Sanders' Dracaena

\begin{tabular}{|c|c|c|c|c|c|c|}
\hline Shade & $\begin{array}{l}\text { Size of planting } \\
\text { material }\end{array}$ & $\begin{array}{c}\text { Gross Income/ } \\
100 \mathrm{ft}^{2} / \mathrm{yr}\end{array}$ & $\begin{array}{l}\text { Cuttings/ } \\
100 \mathrm{ft}^{2} / \mathrm{yr}\end{array}$ & $\begin{array}{c}\text { Total weight/ } \\
100 \mathrm{ft}^{2} / \mathrm{yr}\end{array}$ & $\begin{array}{l}\text { Mean weight } \\
\text { of cuttings }\end{array}$ & $\begin{array}{l}\text { Mean size of } \\
\text { cuttings }\end{array}$ \\
\hline$\%$ & & $\$$ & No. & $L b$ & $L b$ & In \\
\hline \multirow[t]{3}{*}{47} & 5 in, $6.0 \mathrm{~g}$ & $48.43 b^{\prime}$ & $372 \mathrm{c}$ & $6.61 b$ & $18.0 \mathrm{~b}$ & $8.8 \mathrm{~b}$ \\
\hline & 9 in, $15.3 \mathrm{~g}$ & $69.14 \mathrm{a}$ & $493 \mathrm{~b}$ & $9.38 \mathrm{~b}$ & $21.1 \mathrm{~b}$ & $10.1 \mathrm{~b}$ \\
\hline & $1.3 .5 \mathrm{in}, 27.9 \mathrm{~g}$ & $85.32 \mathrm{a}$ & $632 \mathrm{a}$ & $14.10 \mathrm{a}$ & $26.6 \mathrm{a}$ & $11.5 \mathrm{a}$ \\
\hline \multirow[t]{3}{*}{51} & in, 6.0 gr & $30.39 \mathrm{~b}$ & $252 \mathrm{~b}$ & $3.76 \mathrm{~b}$ & $15.0 \mathrm{~b}$ & $7.9 \mathrm{a}$ \\
\hline & 9 in, $15.3 \mathrm{~g}$ & $53.73 \mathrm{a}$ & $395 \mathrm{a}$ & $7.48 \mathrm{a}$ & $19.2 \mathrm{~b}$ & $9.2 \mathrm{a}$ \\
\hline & $13.5 \mathrm{in}, 27.9 \mathrm{~g}$ & $49.79 \mathrm{a}$ & $362 \mathrm{a}$ & $8.51 \mathrm{a}$ & $25.3 \mathrm{a}$ & $10.8 \mathrm{a}$ \\
\hline \multirow[t]{3}{*}{63} & 5 in, $6.0 \mathrm{~g}$ & $42.79 \mathrm{a}$ & 333 a & $5.85 \mathrm{a}$ & $17.1 \mathrm{~b}$ & $8.6 \mathrm{~b}$ \\
\hline & $0 \quad$ in, $15.3 \mathrm{~g}$ & $54.42 \mathrm{a}$ & $398 \mathrm{a}$ & $7.60 \mathrm{a}$ & $20.0 a b$ & $9.6 \mathrm{a}$ \\
\hline & $13.5 \mathrm{in}, 27.9 \mathrm{~g}$ & $57.27 \mathrm{a}$ & $424 \mathrm{a}$ & $8.97 \mathrm{a}$ & $22.6 \mathrm{a}$ & $10.2 \mathrm{a}$ \\
\hline \multirow[t]{3}{*}{76} & 5 in, $6.0 \stackrel{\text { r }}{m}$ & $44.44 \mathrm{a}$ & $350 \mathrm{a}$ & $5.70 \mathrm{a}$ & $15.2 \mathrm{~b}$ & $8.2 \mathrm{~b}$ \\
\hline & 9 in, $15.3 \mathrm{~g}$ & $60.13 \mathrm{a}$ & $456 \mathrm{a}$ & $9.23 \mathrm{a}$ & $21.9 \mathrm{a}$ & $10.3 \mathrm{a}$ \\
\hline & $13.5 \mathrm{in}, 27.9 \mathrm{~g}$ & $58.15 \mathrm{a}$ & $435 \mathrm{a}$ & $8.60 \mathrm{a}$ & $22.3 \mathrm{a}$ & $10.6 \mathrm{a}$ \\
\hline \multirow[t]{3}{*}{92} & 5 in, $6.0 \mathrm{~g}$ & $23.54 \mathrm{~b}$ & $213 a$ & $2.12 c$ & $9.3 c$ & $6.4 \mathrm{~b}$ \\
\hline & 9 in, $15.3 \mathrm{~g}$ & $32.01 \mathrm{a}$ & $250 a$ & $3.51 \mathrm{~b}$ & $14.6 \mathrm{~b}$ & $8.2 \mathrm{a}$ \\
\hline & $13.5 \mathrm{in}, 27.9 \mathrm{~g}$ & $35.05 \mathrm{a}$ & $269 \mathrm{a}$ & $4.82 \mathrm{a}$ & $16.9 \mathrm{a}$ & $8.7 \mathrm{a}$ \\
\hline
\end{tabular}

1 Means followed by one or more letters in common do not differ significantly at the $5 \%$ level.

cumulative evaporation of $1 / 2$ in under the $92 \%$ shade was used as an index of when to irrigate.

The experiment was harvested as soon as all plants yielded a commercial cutting after leaving 4.5 in of original stalk. Thereafter, the cuttings were harvested at commercial sizes, after leaving 2.5 in of additional stalk. The suckers that developed from the undergound stump were harvested as originally done by leaving 4.5 in of stalk. The cuttings were weighed, measured, and their leaves counted.

The cumulative four-year data were converted to gross income/100 
$\mathrm{ft}^{2}$, based on current corresponding size prices for unrooted cuttings. The information was analyzed statistically through variance and the means were tested for significance on a $t$-rank test.

\section{RESULTS AND DISCUSSION}

The results are presented in tables 1 and 2. Table 1 summarizes the results of the effect of size of planting material, while table 2 shows the effects of planting distances. The gross income reflects the most important aspect of the experiment, since it is not only affected by the number of harvested cuttings, but also by their marketing sizes.

A good-size cutting seems to be a determining factor on the success of a new plantation of the Sanders' Dracaena. This fact is definitely related to the shade intensity, as reflected in the results of the experiments. Significant differences were detected at 47, 51, and $92 \%$

TABLE 2. - The effect of planting distance on the production of Sunders' Dracaena

\begin{tabular}{|c|c|c|c|c|c|c|}
\hline Shade & $\begin{array}{l}\text { Planting dis- } \\
\text { tance }\end{array}$ & $\begin{array}{c}\text { Gross income/ } \\
100 \mathrm{ft}^{2} / \mathrm{yr}\end{array}$ & $\begin{array}{l}\text { Cuttings/100 } \\
\mathrm{ft}^{2} / \mathrm{yr}\end{array}$ & $\begin{array}{c}\text { Total weight/ } \\
100 / \mathrm{ft}^{2} / \mathrm{yr}\end{array}$ & $\begin{array}{l}\text { Mean weight } \\
\text { of cuttings }\end{array}$ & $\begin{array}{l}\text { Mean size of } \\
\text { cuttings }\end{array}$ \\
\hline$\%$ & $F t$ & $\$$ & No. & $L b$ & $L b$ & In \\
\hline \multirow[t]{3}{*}{47} & $12 \times 12$ & $38.82 \mathrm{c}^{\prime}$ & 819 a & $14.27 \mathrm{a}$ & $18.2 \mathrm{~b}$ & $9.5 \mathrm{~b}$ \\
\hline & $9 \times 9$ & $56.88 \mathrm{~b}$ & $412 \mathrm{~b}$ & $9.10 \mathrm{~b}$ & $21.9 \mathrm{ab}$ & $10.0 \mathrm{ab}$ \\
\hline & $6 \times 6$ & $107.20 \mathrm{a}$ & $267 \mathrm{c}$ & $6.73 \mathrm{~b}$ & $25.2 \mathrm{a}$ & $11.0 \mathrm{a}$ \\
\hline \multirow[t]{3}{*}{51} & $12 \times 12$ & $21.14 \mathrm{c}$ & $559 \mathrm{a}$ & $10.40 \mathrm{a}$ & $17.7 \mathrm{a}$ & $8.8 \mathrm{a}$ \\
\hline & $9 \times 9$ & $39.41 \mathrm{~b}$ & $295 \mathrm{~b}$ & $6.04 \mathrm{~b}$ & $20.4 \mathrm{a}$ & $9.5 \mathrm{a}$ \\
\hline & $6 \times 6$ & $73.66 \mathrm{a}$ & $155 c$ & $3.32 \mathrm{c}$ & $21.3 \mathrm{a}$ & $9.7 \mathrm{a}$ \\
\hline \multirow[t]{3}{*}{63} & $12 \times 12$ & $24.14 \mathrm{~b}$ & $679 \mathrm{a}$ & $12.98 \mathrm{a}$ & $18.7 \mathrm{a}$ & $9.2 \mathrm{a}$ \\
\hline & $9 \times 9$ & $38.81 \mathrm{~b}$ & $297 \mathrm{~b}$ & $5.82 \mathrm{~b}$ & $19.9 a$ & $9.3 \mathrm{a}$ \\
\hline & $6 \times 6$ & $91.53 \mathrm{a}$ & $178 \mathrm{~b}$ & $3.61 \mathrm{~b}$ & $21.0 \mathrm{a}$ & $9.8 \mathrm{a}$ \\
\hline \multirow[t]{3}{*}{76} & $12 \times 12$ & $24.39 \mathrm{~b}$ & $711 \mathrm{a}$ & $12.66 \mathrm{a}$ & $17.8 \mathrm{a}$ & $9.2 \mathrm{a}$ \\
\hline & $9 \times 9$ & $44.65 \mathrm{~b}$ & $343 \mathrm{~b}$ & $7.50 \mathrm{~b}$ & $19.2 \mathrm{a}$ & $10.4 \mathrm{a}$ \\
\hline & $6 \times 6$ & $93.69 \mathrm{a}$ & $188 \mathrm{c}$ & $3.37 \mathrm{c}$ & $22.3 \mathrm{a}$ & 9.5 a \\
\hline \multirow[t]{3}{*}{92} & $12 \times 12$ & $16.64 \mathrm{c}$ & $380 \mathrm{a}$ & $5.49 \mathrm{a}$ & $12.3 \mathrm{~b}$ & $7.3 b$ \\
\hline & $9 \times 9$ & $27.46 \mathrm{~b}$ & $218 b$ & $3.13 \mathrm{~b}$ & $13.5 \mathrm{ab}$ & $7.8 \mathrm{ab}$ \\
\hline & $6 \times 6$ & $46.50 \mathrm{a}$ & $133 \mathrm{c}$ & $2.03 \mathrm{c}$ & $15.0 \mathrm{a}$ & $8.2 \mathrm{a}$ \\
\hline
\end{tabular}

${ }^{1}$ Means followed by one or more letters in common do not differ significantly at the $5 \%$ level.

shades, but the differences at 63 and $76 \%$ shades were not significant.

The gross income increased over $40 \%$ when the size of the planted cuttings increased from 5 to 9 in mean length or 6 to $15.3 \mathrm{~g}$ mean weight. The difference was more striking at $51 \%$ shade, at which there was a $76 \%$ increase in gross income with the same change in size of the cuttings. No significant differences were detected at 63 and $76 \%$ shade, but at $92 \%$ shade, the change in size brought an increase close to $40 \%$ in the gross income.

The total number of the harvested cuttings and the total and mean 
weight/cutting reflected with little variation the same tendency as the gross income, always in favor of large size cuttings. The mean weight/ cutting was affected significantly in all shade intensities. A large size planted cutting increased the mean weight of the harvested cuttings. The same tendency was observed with the medium size except at 51\% shade, in which the differences were not statistically significant.

The planting distance significantly affected the gross income, number and total weight of cuttings at all shade levels. The mean weight and the size of cuttings were significantly affected only at the low and high shade intensities.

Gross income increased significantly by approximately one third when the planting distance was decreased from $12 \times 12$ to $9 \times 9$ in at $47 \%$ shade. The increase was even greater when planting distance was reduced to $6 \times 6 \mathrm{in}$. The gross income was almost doubled by that reduction. That same tendency was observed for the number of cuttings/ year and total weight/100 $\mathrm{ft}^{2} /$ year. At the same time the average size and weight of the cuttings decreased with a decrease in planting distance.

The changes in the planting distance influenced more markedly the gross income at the $51 \%$ shade. The gross income was almost doubled with the changes in the two planting distances. The same tendency was observed with the number of cuttings and total weight/100 $\mathrm{ft}$ \% year. On the other hand, no significant differences were observed in the mean weight and size of the cuttings at the three planting distances.

The statistical differences were more pronounced in the 63 and $76 \%$ shades, in which gross income increased more than twice with the reduction of planting distance from $9 \times 9$ to $6 \times 6$ in. The same was true for the number of cuttings harvested/year and total weight/100 ft²/ year. On the other hand, mean weight and size were not significantly affected by the change in planting distance at those two shade intensities.

In $92 \%$ shade, as in $47 \%$, gross income, number of cuttings, total weight, mean weight, and size of the cuttings were significantly affected by planting distance. A significant increase close to $40 \%$ was obtained in gross income when the cuttings were planted at $9 \times 9$ in apart instead of $12 \times 12$, or $9 \times 9$ instead of $6 \times 6$ in apart. The same tendency was observed in the number of harvested cuttings and total weight/100 $\mathrm{ft}^{2} /$ year. On the other hand, mean weight and size decreased with the reduction in the planting distances.

The common practice of most nurserymen is to establish a new plantation with the remnants left after selecting the material for exportation. Those cuttings undoubtedly are not the best planting material to start a new plantation. At the same time, that new 
plantation should be planted close enough to make the best use of the land. Sanders' Dracaena seems to be adapted to varying light conditions such as are found in the Island. The self-shading at the close planting distance does not affect yield, as revealed by the gross income, number of cuttings, and total weight.

The results have shown conclusively that all new plantings should be started with healthy, well-developed cuttings. Those cuttings should be planted $6 \times 6$ in, a planting distance that will stimulate the production of smaller size cuttings but in greater number. For bigger size cuttings, the plants must be planted farther apart.

\section{RESUMEN}

Se estableció un experimento con Dracaena sanderiana, Hort. para observar el efecto del tamaño del material de propagación y la densidad de siembra en la producción. Se escogieron tres tamaños distintos del material de propagación; 4 a 6,8 a 10,12 a 15 pulgadas. Los pesos promedios correspondientes a cada tamaño fueron $6,15.3$ y $27.9 \mathrm{~g}$ respectivamente. Este material se sembró arraigado a tres distancias de siembra: $6 \times$ $6,9 \times 9,12 \times 12$ pulgadas en un diseño factorial. Este experimento se efectuó bajo cinco niveles de sombra a base de tejidos de polipropileno: 47, 51, 63, 76 y $92 \%$. El medio de cultivo fue una mezcla 3:1 por volumen de arena Cataño y turba de pantano desmenuzada, en sementeras de hormigón de $4 \times 40$ pies. Las plantas se abonaron cuatro veces alaño con un abono 16-4-8, para suplir alrededor de 500 libras de N/acre y año. Se siguió un procedimiento de cosecha dejando $4^{1 / 2}$ pulgadas del tallo en el primer corte y $2^{1 / 2}$ en los siguientes. Cada tratamiento se repitió dos ǔeces.

El peso medio y el largo medio de los esquejes cosechados fueron mejores cuando se sembraron esquejes grandes y pesos proporcionales al tamaño. Sin importar la densidad de la sombra, a una distancia de siembra de $6 \times 6$ se producen más que esquejes en la de $9 \times 9$ pulgadas; un ingreso mayor que la de $12 \times 12$. En distancias menores los esquejes por lo general son más pequeños aunque todos son comerciales.

\section{LITERATURE CITED}

1. González-Villafañe, E. y Cucalón, M. Análisis de las Importaciones y Exportaciones de Plantas Ornamentales y Flores de Puerto Rico, Est. Exp. Agr. Univ. P.R., Bol. 235, 1974.

2. Rodríguez, S. J., Rivera-López, C., and Santiago, A. Variation in Chemical Composition of Dracaena sanderiana Leaves as Influenced by Leaf Maturity and Shade Intensity, J. Agric. Univ. P.R. 57(2): 136-48, 1973.

3. - and - Influence of nitrogen applications of leaf nutrient content of Dracaena sanderiana, Hort. leaves, J. Agric. Univ. P.R. 60(3): 344-7, 1976.

4. - and - Effect of six levels of nitrogen on the growth of Sanders' Dracaena (Dracaena sanderiana, Hort.) at a 47 percent shade, J. Agric. Univ. P.R. 61(3): 314-8, 1977. 